\title{
THE DEVELOPMENT OF POST-APARTHEID SOUTH AFRICA IN LIGHT OF THE INSTITUTIONALIST PERSPECTIVE: A CRITICAL REVIEW
}

\author{
João Paulo Davi Constantino' \\ Robson Dias da Silva ${ }^{2}$ \\ Georges Flexor ${ }^{3}$
}

(c) (†)

\section{Introduction}

In September 2015, the British magazine The Economist released an article that questioned differences in development patterns, even internal ones, among emerging economies such as Mexico, Brazil, Russia and South Africa. It recommended that, besides making the right choice for macroeconomic policies, they should take into consideration factors such as security of contracts, high-quality public services and transparent budgets to be trustworthy to economic agents ${ }^{4}$; in other words, it was necessary building institutions the population could trust in.

Although advocating for the institutionalist perspective of economic development is nothing new5, the idea that "good institutions" and "good governance" were necessary to promote development has gained prominence

\footnotetext{
I Universidade Estadual de Campinas. Campinas, Brazil. E-mail: j207529@dac.unicamp.br. ORCID: https://orcid.org/oooo-0002-3585-639X

2 Universidade Federal Rural do Rio de Janeiro. Rio de Janeiro, Brazil. E-mail: robsondsilva@gmail.com. ORCID: https://orcid.org/oooo-0ooI-7679-4722

3 Universidade Federal Rural do Rio de Janeiro. Rio de Janeiro, Brazil. E-mail: gflexor@ gmail.com. ORCID: https://orcid.org/oooo-0003-0859-2568

4 See https://www.economist.com/leaders/2015/09/19/the-two-mexicos.

5 Cf. (Gerschenkron ig62).
} 
in the political and economic debate in the late $20^{\text {th }}$ century, in convergence with neoclassical propositions and with the discourse of multilateral organizations. Based on the agenda for developing countries, "good institutions" and "good governance" are synonymous with greater protection of property rights, independent central banks focused on stabilization policies, transparent corporate governance, among others prescriptions crystallized in the Washington Consensus, which are translated into greater economic liberalization and market deregulation. The acceptance of these recommendations did not happen in a historical vacuum.

For some countries, this change went against social formations that had already presented structural cracks. It was the case of South Africa, which not only spent much of the $20^{\text {th }}$ century dealing with a primary-export economy that depended on foreign capital from multinational corporations (Marais 20II), but was also ruled by an authoritarian and segregationist political regime. After years of political struggle by liberation movements, led by the African National Congress (ANC), the democratic transition started in mid-I990s and met the diffusion of new development conventions: multilateral institutions and developed countries started recommending a series of institutional and governance reforms combined to policies focused on eradicating poverty mainly for African countries. Therefore, since the I990s, South Africa has been a special example of drastic institutional transition, economic and political change occurring at the same time.

This work aims to present a critical analysis of the impacts on the diffusion of new international institutional and governance standards in the economic development of South Africa (in its broad sense). The study was divided into four sections, besides the introduction and the final considerations. The second section addresses the association between institutions and economic development in recent academic literature. The third section presents the methodology applied to assess the development of democracy, private and intellectual property rights, financial institutions, tariffs and commercial protection in the country, as well as of welfare and labor protection institutions. The fourth section briefly addresses the South African democratic transition period back in the I990s, highlighting its institutional and political shift towards a neoliberal model capable of favoring monetary stability and "big business", despite the chronic inequalities yet observed in the country nowadays. The fifth section makes an in-depth analysis of each of these institutions in the South African context and investigates the extent to which they have resulted in economic growth, reduced inequalities and have enabled better quality of life for the South African population. It was possible concluding that the association between institutions and economic 
development is more complex than the one presumed by many economists and international organisms, since it does not present a simple and linear correlation. Moreover, it was observed that developing countries need to implement structural transformations that are beyond the sole power of market mechanisms.

\section{Institutions and economic development: from the New Institutional Economics to the critical view of Ha-Joon Chang}

The interest in bringing institutions to the core of the debate about economic development has gotten significant contribution from the New Institutional Economics (NIE) in recent decades, mainly since the I990s. According to authors who follow the "new institutionalism orthodoxy" (Castellano 20I2), there would be a series of historical evidence capable of proving the association between institutions and economic development. These researchers interpret the progress of nations as a process deriving from basic economic development forces observed in decentralized relations of market institutions. Thus, NIE discourse is crystallized by the logo "institutions matter" (Tylecote 20I6) for development purposes, which highlights the direct relationship established between the institutional framework of a given country and its economic growth variables (Acemoglu and Robinson, in "Por que as nações fracassam: as origens do poder, da prosperidade e da pobreza" [20I2]; North, Wallis and Weingast, "Violence and Social Orders: A Conceptual Framework for Interpreting Recorded Human History" [2009]; Tylecote 20I6; Zanden 2009).

The term New Institutional Economics was introduced by American economist Oliver Williamson (I975). According to Richter (2005), two branches of the New Institutional Economics have developed from the pioneering works conducted by Ronald Coase (I937; 1960) namely: Transaction Cost Economics (Williamson I985); and New Institutional Economics of History (North I986). According to North (I990), who won the Nobel Prize in Economics, institutions arise from uncertainty and from the need of overcoming transaction costs, for instance, the costs of establishing, monitoring and controlling agents' relations in market-failure environments ${ }^{6}$.

Most studies based on this tradition (North I97I; 198I; 1990; Landes I998; Zanden 2009; Acemoglu, Johnson and Robinson 2005, 2012;

6 Cf. (Coase 1937); (Williamson 1979); (North 1986; 1990); (Gala 2003). 
Bates I98I, I997; Bates, Coatsworth and Willianson 2007) have inferred that, nowadays' developing countries are those that somehow still have undermined institutions that favored free competition and smooth Market functioning. This interpretation features developing countries as the ones that have adopted institutional arrangements that reduce productivity, destabilize contracts and create a property right-insecurity environment. This "vicious path" (North I990; Medeiros 200I) would have been the one followed by the Spanish colonies in Latin America, and its solidification would be the reason why their economic development is permanently blocked. On the other hand, the "virtuous" path taken by the current developed economies is featured by the Anglo-Saxon model of market economy.

Following North's tradition, economist Daron Acemoglu and political scientist James A. Robinson, both in Institutions as the fundamental cause of long-run growth (2005) and in Why Nations Fail (2012), have defined institutions as rules for human game-shaping interactions. According to Acemoglu, Johnson and Robinson (2005), economic institutions are important because they influence the structure of incentives available in a given society, as well as help allocating resources in order to be more efficiently used. In addition, these authors have shown how institutional differences are determining aspects for divergences observed in prosperity levels between countries colonized by Spain and England. If on the one hand, theories by Acemoglu, Johnson and Robinson (2001; 2002; 2005) rejected geographic and cultural explanations for the success, or failure, of nations, on the other hand, they have put their hopes for development in institutions that encouraged free markets, as well as in the private sector.

Since the late $20^{\text {th }}$ century, the aforementioned concept has been adopted as mainstream discourse, which echoes on the agendas of international organizations such as the International Monetary Fund (IMF), the World Bank and the World Trade Organization (WTO). Governance reforms and market-oriented institutional changes are seen as essential to promote economic development. Institutionally strong states - i.e., who are capable of guaranteeing security and the rule of law for the largest number of individuals possible, but, above all, who are capable of guaranteeing property rights - are also essential (Bates, Coatsworth e Willianson 2007; Buchanan 2008; Boettke and Fink 20II; Dhonte and Kapur I996; Glaeser et al. 2004; La Porta et al. I999; Kaufmann, Kraay and Zoido-Lobaton i999).

It is possible to find an alternative approach to the theoretical association established between institutions and economic development, as well as in the greater framework of trust in the markets as economic growth 
and development drivers. According to Chang (2OII), NIE has two main theoretical issues, the first one lies on causality, according to which, NIE sees association between institutions and economic development as a linear process that goes from institutions to economic development. The second issue refers to the linear, static and simplistic ways often substantiating the understanding about this association (Chang 2007; 20II). Such an understanding ends up leading to the assumption of the existence of a universal model of "good economic and political institutions", as well as to the belief that such models could be extrapolated to other countries, based on the experience of powerful Western countries (Castellano 20I2; Evans 2004; 20I0; Portes 2007; Przeworski 2004).

Chang's (20II) main criticism to the mainstream discourse about institutions lies in the fact that it describes the association between institutions and economic development in a simplistic, linear and static manner. Institutional changing processes that advocate for the market are often recommended to developing countries without taking into account several aspects ("one-size-fits-all" model) likely involved in these processes that do not follow closed models (Chang 2004). Moreover, Chang (2004) criticizes the excessive focus on private property rights. Although economies without any property rights protection, where uncertainty almost permanently prevails, are clearly not the best environment for development, there is a belief in property rights as a "good-in-itself" institution (Chang 2004, I44).

\section{Some methodological aspects: Institutionalist analysis of a developing economy}

The idea that a "package of good institutions" (Chang 2004) would be essential to enable economic growth (Aron 200I; Kaufmann, Kraay and Zoido-Lobaton I999); as well as that the development history of advanced countries would be marked by the application and evolution of this group of institutions (Bates, Coatsworth e Williamson 2007; North I990; Acemoglu and Robinson 20I2), has gained room in the economic discourse since the late $20^{\text {th }}$ century.

However, applying this institutionalist approach to better understand the economic development of a country facing severe economic and social issues is a great challenge, since many institutional changes undergone by this country are so recent that most statistical data or censuses about specific institutions, or specific analyses, may not yet be available. Therefore, 
analyzing institutional changes in South Africa, as evident as some of them may be, leads to some challenges.

The first challenge refers to the application of a traditional institutionalist perspective to favor historical treatment and its effects on the economic development of a given society — path dependence - , within the South African context. Although the analysis to be conducted aims at covering the democratic years of the new South Africa after the end of apartheid, one cannot deny the effects of this regime on, and the roots it left in, the development of South African capitalism. The short time series covering this analysis will be compensated by the comprehensive analysis of the institutions.

Thus, the hypothesis raised in this work is that adapting to the "good institution" models did not necessarily result in economic development, or even in greater economic growth, in the post-apartheid South Africa. This study has also presented how, in some aspects, the country has shown better performance in institutional indicators than some developed countries, although it did not improve the quality of life of its population or reduced its deep inequalities.

The institutions analyzed in the next section were the ones mostly defended by the mainstream institutionalist discourse and by NIE as essential to enable economic development - the so-called "good global standard institutions"7. The herein analyzed institutions were democracy (universal suffrage and worldwide governance indicators such as voice and accountability, rule of law, political stability), property rights (mainly intellectual property rights), financial institutions (banking system, central bank), commercial tariffs (trade opening level) and social and labor protection institutions. Furthermore, the timeline of analysis has privileged the decades following the South African democratic transition, when several institutional changes and reforms took place based on the neoliberal approach (I994-20I4). However, it has also outlined the history of these institutions in case their origin dated back to times prior to the assessed one.

\section{Democratic transition and neoliberalism in South Africa: (mis)guided paths of post-apartheid}

Although the South African apartheid regime was only institutionally formalized in 1948 by the Afrikaans National Party, the roots of segregation observed in it date back to the $19^{\text {th }}$ century. The social panorama by I9IO

7 "Global Standard Institutions (GSI)", Chang (20II). 
encompassed a great majority of black individuals (who were the labor force to be exploited and did not have political rights) and the white minority who had voting rights (Fonseca-Satter 20II). In the meantime, several laws and acts have been enacted and evidenced the segregationist nature of the country's economic and political elites and a state capitalism type emerged in South Africa that allowed the country to grow fast (Fonseca-Satter 20II; Pereira 20I0).

The transition to a democratic regime in South Africa started in I994; this time meets the period marked by the international neoliberal agenda driven by the end of the Cold War and by globalization. Indeed, despite the legacy of apartheid, mainly the profound social and racial inequality in the country, the South African economic policy has embraced a conservative marked-oriented program instead of making deep structural repairs. The abandonment of a more critical stance by the ANC represented, in its turn, a true "elite pact", since the ANC elite organized the elections, whereas the white elite managed to maintain their interests and economic privileges (Bond 2000; Taylor 2016).

This "transition of elites" (Bond 2000, I6), which has validated an economic policy that prioritized private initiative and property rights, was added to the GEAR (Growth, Employment and Redistribution) governmental plan from I997. However, it did not happen overnight, but resulted from a process whose origins date back to the ig8os. Part of this process is linked to the involvement of Thabo Mbeki (who would become the country's future president) with the South African business elite and with international financial institutions such as Goldman Sachs (Segatti and Pons-Vignon 2013).

The economic policy adopted by the South African post-apartheid government was summarized in three main dimensions: European approach to social policy, along with the fear of risks of personal dependence on the state, in association with the East Asian approach to economic growth - based on conservative macroeconomic parameters (Hirsch 2005). However, these changes in South Africa's institutional settings during the post-apartheid years did not necessarily result in better economic performance. The average GDP per capita annual growth rate in South Africa declined from approximately I,9\% per year, in I960-1980, to approximately I,5\% per year, in I994-20I4, or even $0,3 \%$ per year, if we consider the period I980-20I4 (Graph I). "Good institutions" alone do not deliver economic development, as the study will show in the next sections. 


\section{Graph 1: South Africa GDP per capita growth (annual \%)}

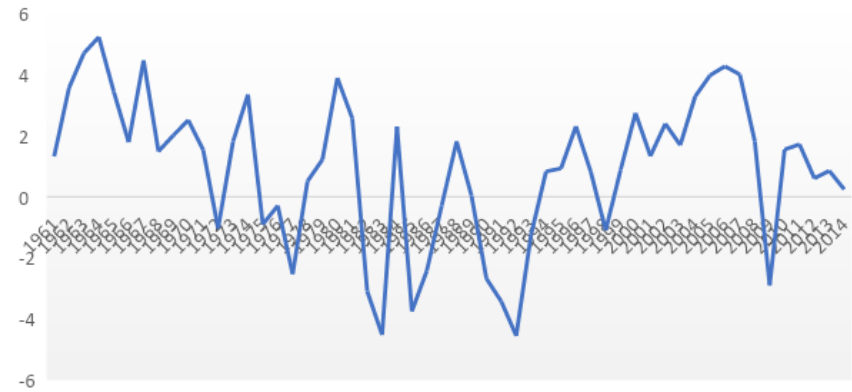

Source: World Bank Data.

\section{Institutions and economic development in post-apartheid South Africa}

The South African democratization process took place at a time when the role played by institutions gained importance in political and economic debates. Several analysts, mostly the ones from multilateral organizations such as World Bank and IMF, have started interpreting the crises and structural issues of developing economies as institutional and governance issues (Aron 200I; Fallon and Pereira de Silva I994; Kaufmann, Kraay and Zoido-Lobaton I999; Riley I995; IMF 2000). International recommendations, mainly the ones regarding African countries, have headed towards the implementation of a package of good institutions and focused on reducing poverty, as well as on improving education and health (Blackden I999; Christiaensen, Demery and Paternostro 2002; Coudouel, Dani and Paternostro 2006; Marc, Graham and Schacter I994; World Bank 1996). The next subsections analyze South African institutional development in light of this debate, as well as to what extent compliance with NIE discourse models has contributed to the economic development of the country.

\section{Democracy}

Although successful, the South African transition into an institutionally democratic regime only took place after a long process marked by violence and repression. However, it did not change the significant socioeconomic 
inequality between the white minority and the black majority in the country (Bond 2000; 2004; Holdt 2013). Universal suffrage was established in the country in I994, after the country's first multiracial election, which brought Nelson Mandela to power. The democratic constitution approved in December 1996 was considered one of the most progressive constitutions in the world, since it set clear parameters for human rights, freedom of expression, religion and equal rights.

According to defenders of "good governance", South Africa has accomplished significant advancements in some of the indicators necessary to build democracy since the promulgation of its first democratic constitution. Such indicators, such as "voice and accountability", "rule of law", "political stability", among others, are components of the World Bank Group's Worldwide Governance Indicators proposed by Kaufmann, Kraay and Zoido-Lobaton (I999). These indicators reflect to which extent citizens of a given country are able to pick their government and collect their rights. They also measure the perception of trust in the law and in rules of society, as well as the likelihood of having their government destabilized by unconstitutional trends.

Graph 2 shows the position of South Africa (based on percentile) in these indicators: $O$ is the lowest position and, therefore, reflects the worst performance in this indicator, whereas Ioo is the best performance. Overall, South Africa presents a relatively good position in these aspects, mainly in relation to the "rule of law" - which rose from the $55^{\text {th }}$ percentile to approximately $59^{\text {th }}$ in 2010 , as well as to the $64^{\text {th }}$ percentile, in 2014. Although "Voice and Accountability" presented a downward trend since 2004, as well as worse position in 2010 than in 1996 (approximately $67^{\text {th }}$ and $73^{\text {rd }}$ percentile, respectively), its rank remained above the average of upper-middle income countries, and higher than that of other African countries - it ranked the $68^{\text {th }}$ percentile in 2014 .

With respect to "political stability and violence", the South African rank is below the average of upper-middle income countries, although it showed progress and approached this average from 2006 on. Similarly, Looney (20I4) has compared these very same South African indicators to those of "emerging economies" such as Mexico, Malaysia, Turkey and Indonesia. South Africa presented better performance than each of these countries, on average. This outcome highlights the political gains acquired by the country, as well as its relative high governance levels over the years. 


\section{Graph 2: Governance Indicators, South Africa and mean of upper-middle income countries, 1996-2014}
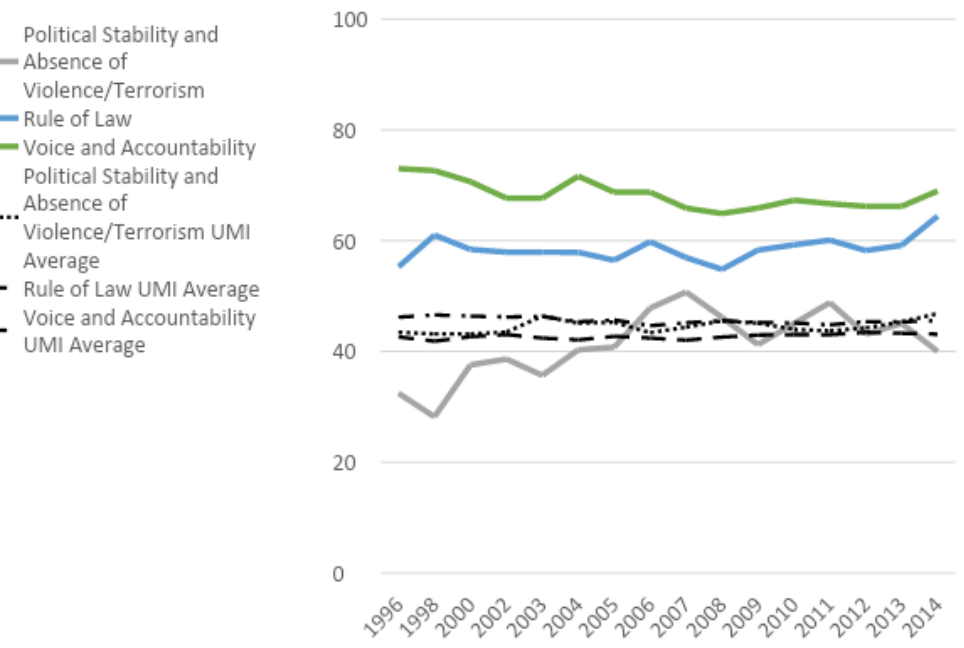

Source: Worldwide Governance Indicators, World Bank.

The Ibrahim Index of African Governance (IIAG) ${ }^{8}$ was another indicator capable of evidencing South Africa's progress on democracy. This index measures the performance of institutions in African countries in comparison to governance, which, in its turn, is defined as "the provision of political, economic and social assets citizens have the right to expect from their respective states"9. It comprises categories such as "Security and the Rule of Law", "Participation and Human Rights", "Sustainable Economic Opportunities and Human Development", which, in their turn, comprise other subcategories. Nowadays, South Africa ranks the seventh position in the ranking of 54 African countries; its governance performance is well above the African average (Graph 2), mainly in subcategories such as "legitimacy of electoral processes" and "holding free and fair elections".

However, the outcome of these indicators presents some paradoxes that make the analysis of the association between democracy and economic development even more complex. This association in the South African case elicits some contradictions that test the supposedly linear and inseparable view between democracy and economic development.

\footnotetext{
8 The time series updated for this index starts in 2008 .

9 See http://iiag.online/
} 
Per capita income in South Africa when the universal suffrage was instituted for the I994 elections (consolidated by the 1996 Constitution) was $\$ 3,445 \cdot 23^{\text {Io }}$. It was well above that of other African countries that had enacted universal suffrage decades earlier. On the other hand, South Africa per capita income faced a downward trend from its democratic transition until $2002-$ it reached US\$2,502.277. Thus, although one cannot deny the advancements achieved by South Africa through democracy introduction in the country, mainly in the form of universal suffrage and political rights of citizens, it is not possible to establish a simplistic and linear association between variables featuring liberal democracy and economic growth. Democracy is more than a "requirement" for growth; it is part of a larger historical process of social transformation (Alence 2009).

\section{Graph 3: Ibrahim Index of African Governance in South Africa and the average for the African continent, 2008-2014}

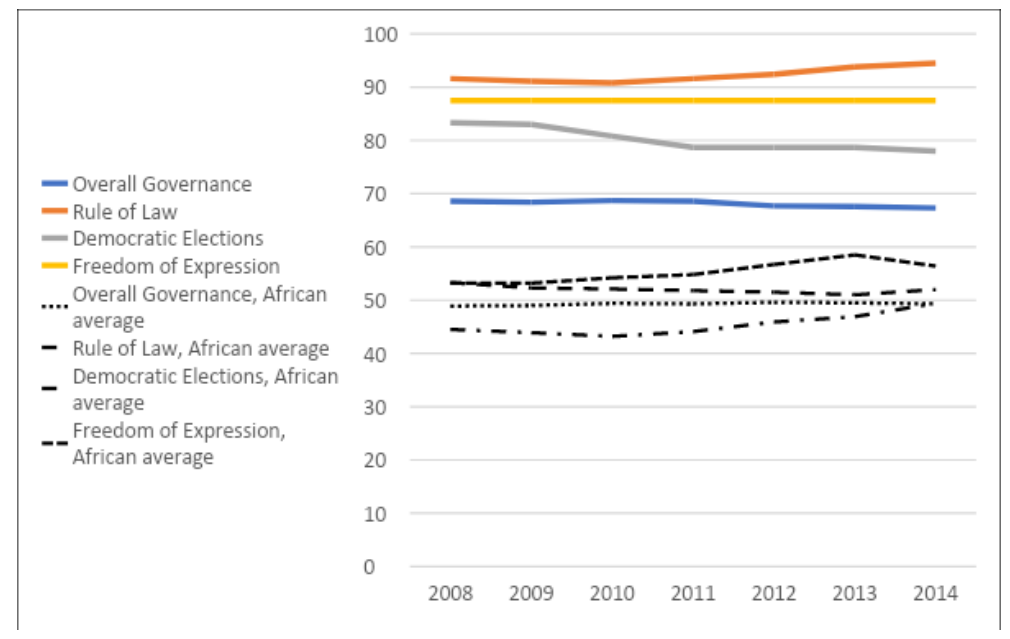

Source: IIAG Data Portal

\section{Property rights}

The protection of property rights occupies central place among institutions addressed in the neoliberal institutionalist discourse as essential for economic development. Property right regimes are seen as essential tools

Io World Bank data, in current dollars. 
to encourage investment, work and, therefore, economic growth (Acemoglu and Robinson 2005; 2012; Aron 2001; Clague et al. 1996; Soto 2000; Knack and Keefer I995; Gala 2003; North I990; Tylecote 2016).

The 1978 Patent Act was the first patent law enacted in South Africa; it addressed the registration and granting of patents associated with commercial, industrial or agricultural activities. The Copyright Act (I978) was also drafted in that very same year. Most of the content in these laws, as well as that of previous laws associated with the protection of intellectual property rights - such as the I967 Performer's Protection Act -, was revised in the I997 Intellectual Property Laws Amendment Act. The introduction and revision of these laws have been increasingly influenced in order to comply with the standard of an international regime for intellectual property rights. South Africa became a member of the Patent Cooperation Treaty (PCT) in I999; this treaty aims at protecting patent rights for inventions simultaneously developed in different countries, based on the application of an international patent. It is important emphasizing that even before the official patent law was enacted in South Africa, the country was already a member of the Paris Convention for the Protection of Industrial Property since I947. In addition, the country has joined the World Intellectual Property Organization (WIPO) Convention in I975.

According to WIPO, South Africa has granted the total number of 5,748 patents through its official office, between residents and non-residents, in the year it drafted its first Patent Law, whereas $6,8 \mathrm{I} 7$ patents were granted in the following year (I979). The number of patents granted to South African residents has decreased since its transition to democracy in 1994 - from 942 (in I994) to I40 (in I999). The number of granted patents has increased and stabilized since the 2000s; 822 patents were granted to South African residents in 20I0, although this number was still smaller than the one recorded in I994. This number has decreased again by 2015 , when 453 patents were granted to South African residents ${ }^{\mathrm{II}}$.

Patent granting to non-residents has shown an upward trend in I994 ( $\mathrm{n}=3,889)$ and I998 $(\mathrm{n}=6,663)$; then, there was a sharp decrease to $\mathrm{I}, 858$ patents granted in $200 \mathrm{I}$. After 2004 , the number of patents granted to non-residents was smaller than that granted to residents; this trend remained until 2009. It is possible seeing a paradox between the level of per capita income and the analyzed institution - in this case, intellectual property rights measured through patent granting. Per capita income in the year South Africa has instituted its Patent Law was US\$ I,722.227 and, despite small

II Direct patents and those held by PCT. 
advancements, this level remained almost unchanged until the mid-I980s, when it recorded US\$ I,807.977 in I985.

\section{Graph 4: Total number of patents granted in South Africa, 1994-2014}

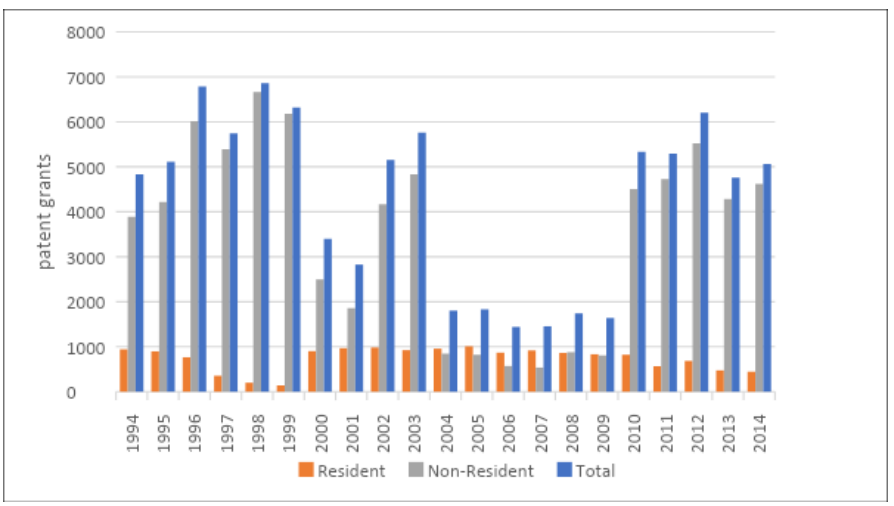

Source: WIPO and World Bank.

Although the country recorded peaks in patent granting at several points in the series, mainly in the mid-I990s $(6,783$ patents in 1996$)$, the per capita income level has kept the decline rate at least until 2002, when it reached US\$2,540.00 (current dollars). On the other hand, the level of per capita income increased from US\$2,502.277 in 2002 to US\$ $5,760.805$ in 2008 , as the total number of granted patents tended to fall; it ranged from 5,759 patents in 2003 to 1,742 , in 2008.

South Africa has presented excellent performance in recent decades in the protection of intellectual property rights, which is measured based on the International Property Rights Index (Table I) ${ }^{\mathrm{I} 2}$. This index measures three basic dimensions, namely: "legal and political environment", "protection of physical rights" and "protection of intellectual property rights". The last dimension is further divided into subcategories such as "protection of intellectual property rights", "protection of patent rights" and "copyright protection".

I2 See https://www.internationalpropertyrightsindex.org/ 
Table 1: Patent Right Protection Index (1960-2005) in developing countries

\begin{tabular}{lllll}
\hline Countries & $\begin{array}{l}1960-1990 \\
\text { (average) }\end{array}$ & 1995 & 2000 & 2005 \\
\hline South Africa & 2.94 & 3.39 & 4.25 & 4.25 \\
Brazil & 1.22 & 1.48 & 3.59 & 3.59 \\
China & 1.33 & 2.12 & 3.09 & 4.08 \\
India & 1.03 & 1.23 & 2.27 & 3.76 \\
Mexico & 1.19 & 3.14 & 3.68 & 3.88 \\
Nigeria & 2.50 & 2.86 & 2.86 & 3.18 \\
Russia & - & 3.48 & 3.68 & 3.68 \\
\hline
\end{tabular}

Source: Park (2008).

Protection of property rights remains the main recommendation of the institutionalist discourse for the progress of developing economies. However, it is fallacious to think that this is a good thing in itself. It is not uncommon for the protection of intellectual property rights to oppose social justice promotion; thus, it is necessary taking into account the significant social effects resulting from restrictions imposed to technological progress in developing countries. The economic performance of developing countries that did not do so well in protecting patent rights was better than that of South Africa. The growth rate of South African annual per capita income, for example, was one of the lowest between 1994 and 2010 in comparison to other BRICS countries ${ }^{13}$.

\section{Financial Institutions}

The Central Bank of South Africa (South Africa Reserve Bank, SARB) was launched in I92I based on the I920 Currency and Banking Act. When it was created in I92I, the country became the fourth nation to establish a central bank outside Europe and the United Kingdom; the remaining three were the United States States, Japan and Java.

When it comes to political independence and autonomy, which are considered essential elements by the World Bank and the IMF, the South I3 See Bond (2013) for the analysis of South African performance in the context of BRICS. 
African central bank has a considerable level of autonomy to carry out its duties. According to the 1996 Constitution, "in pursuit of its primary object, [it] must perform its functions independently and without fear, favor or prejudice" (Republic of South Africa I996). With respect to its ownership, at the time it was created, SARB followed most central banks around the world, which had most of their shareholders of private origin.

The regulation of the South African banking system is performed by SARB, based on the I990 Banks Act and on the I993 Mutual Banks Act. Nevertheless, there was gradual institutional development regarding the regulation of financial institutions. Since the late $20^{\text {th }}$ century and early $2 \mathrm{I}^{\mathrm{st}}$ century, South Africa has been implementing several institutional changes to meet the international standard. These market-oriented changes were implemented in the early $20^{\text {th }}$ century, when the country already had a Central Bank established, even before other developed nations had it. However, it was unable to reach the level of economic growth it achieved in the I96os-I980s. When it comes to the group of institutions in the financial sector, the cause and effect relations between institutions and South African economic development become more paradoxical and often hard to identify ${ }^{\mathrm{I}}$.

\section{Tariffs and commercial opening level}

South Africa was one of the founding countries of GATT (General Agreement on Tariffs and Trade) in I948, when there was no differentiation between developed and developing countries within it. From ig6o on, when GATT allowed this differentiation to enable developing countries to get some type of specific treatment, the South African government opted to maintain the status of developed country within the agreement; in practical terms, it meant further and faster cuts to protectionist measures (Hirsch 2005). The period of the South African democratic transition was marked by the re-entry of its economy in the world stage, based on a fast trade liberalization process (Bhorat et al. 2013).

The fall of trade barriers was quite abrupt after democratization (Barbosa and Tepassê 2009). The Minister of Commerce and Industry from I994 to I996, Trevor Manuel, who were also Minister of Finance in I999, considered that inserting the South African economy into the world would be a challenging task, mainly due to the legacy of an economy that he considered non-competitive and protectionist (Hirsch 2005). South Africa

I4 When it established its legislation for the regulation of the banking sector, for example, the Banks Acts of I990, South Africa already had a per capita income of approximately US \$3,I82. 
quickly became one of the developing countries with the highest degree of trade openness; it has even exceeded the tariff liberalization requirements demanded by the World Trade Organization since it became a member-country (Pons-Vignon and Segatti 2013) (Table 2).

Table 2: Mean tariffs on imports of manufactured products (\%), developing countries, 1996-2010*

\begin{tabular}{llllll}
\hline Countries & 1996 & 2000 & 2006 & 2008 & 2010 \\
\hline South Africa** & 19.8 & 9.0 & 8.3 & 7.4 & 6.9 \\
Argentina & 11.9 & 12.8 & 8.6 & 8.6 & 9.0 \\
Brazil & 13.4 & 14.7 & 9.8 & 10.5 & 10.7 \\
China & 21.7 & 16.2 & 8.6 & 8.2 & 7.6 \\
Egypt & - & 23.8 & 14.1 & 10.0 & 9.4 \\
Ethiopia & - & - & 18.6 & 17.8 & 17.8 \\
India & 37.6 & 30.4 & 13.1 & 8.4 & 7.2 \\
Russia & 11.9 & - & - & 9.4 & 6.5 \\
\hline
\end{tabular}

Source: United Nations Conference on Trade and Development (UNCTAD) * Applied consolidated rates.

** Data from 1996 to 1999 refer to the South Africa Customs Union (SACU).

Economic integration took place, mainly in South Africa, after the years of isolation brought about by the apartheid regime, which turned foreign policies into a strategic element for the new government (Barbosa and Tepassê 2009). Cooperation in Southern Africa Customs Unions (SACU), which was increasingly supported in versions presented by the European Union and multilateral institutions, represents the market modality established in the early $20^{\text {th }}$ century; this modality aims at reducing customs tariffs and barriers to economic activities (Visentini 20I0). Another initiative towards a free trade zone lies on the integration to the Southern Africa Development Community (SADC) in I994, which signed an agreement in I998 to decrease tariff barriers for a I2-year period, in compliance with WTO standards — this process started in South Africa (Hirsch 2005). However, the drop in tariffs was not enough to provide a level of growth in per capita income comparable to that of previous decades, when mean tariff levels were much higher. The 
mean growth rate of per capita income recorded for the I960-I980 period was $2.3 \%$, whereas the rate recorded for the I994-20I0 period was I. $4 \%^{\mathrm{I5}}$.

\section{Social welfare and work protection institutions}

The last point to be analyzed lies on the development of social welfare institutions and of those that regulate work in South Africa, with emphasis on the 1996 Constitution, which is considered one of the most progressive constitutions in the world. Institutions that "support the weaker segments of society have always been necessary to guarantee social stability" (Chang 2004, I76; Polanyi 2000 [I944]). These mechanisms and institutions in South Africa were delayed for even longer by a regime that marched against History for decades. The institutional framework of apartheid has contributed to stifle levels of poverty, as well as to social and economic inequality. These two factors have turned, and still turn, the broad and democratic establishment of adequate social welfare institutions into a challenge. The provision of these institutions in rural South Africa is an even more complex topic, since apartheid-control measures aimed at removing the black population from urban centers have favored the formation of isolated rural areas with high unemployment rates and precarious housing and education conditions (Hirsch 2005).

In order to deal with this legacy of racial discrimination and with social imbalances generated by it, the 1996 Constitution committed itself to improve the quality of citizens' life, by designating the South Africa Human Rights Commission (SAHRC) as the official monitor of public departments and state agencies accounting for the application of institutions that asserted the socio-economic rights of South African citizens. In I994, the new government had already committed to the International Covenant on Economic, Social and Cultural Rights (ICESCR), which was one of the biggest treaties focused on protecting economic and social rights at that time (Seleoane 200I).

The commitment to the ICESCR has established clauses regarding working conditions - sanitary, working environment, equal opportunities, fair wages and salaries, limitations on working hours, right to strike, among others - , as well as social security, adequate housing and health standards, proper education, among others (Seleoane 200I). The South African Constitution aimed at meeting these conditions by including specific sections for such institutions, in an attempt to loosen apartheid ties and to enable political initiatives to combat poverty and inequality.

I5 World Bank data. 
Work-regulating institutions have been gradually introduced since then, and such an introduction has broken patterns that have segregated workers from different races and sexes for years. By I999, most of the main institutions responsible for regulating the South African labor market had already been established, a fact that strengthened the struggle for labor and union rights with a historic record in South Africa (Table 3).

\section{Table 3: Important new labor laws since 1994}

\begin{tabular}{|c|c|c|}
\hline Law & Main goal & Year \\
\hline Labor Relations Act & $\begin{array}{l}\text { Provides the framework for collective bargain- } \\
\text { ing, union right, right to strike, dispute resolu- } \\
\text { tion, among others. }\end{array}$ & $1995-1996$ \\
\hline $\begin{array}{l}\text { Basic Conditions of } \\
\text { Employment Act }\end{array}$ & $\begin{array}{l}\text { Provides the framework for the application of } \\
\text { minimum standards to workers who are not } \\
\text { covered by the LRA and of overall minimum } \\
\text { standards regarding working hours, dismissal } \\
\text { procedures, overtime and restrictions on child } \\
\text { labor. }\end{array}$ & 1997 \\
\hline Employment Equity Act & $\begin{array}{l}\text { Eliminating race or sex discrimination in large } \\
\text { firms. }\end{array}$ & 1998 \\
\hline $\begin{array}{l}\text { Skills Development Act } \\
\text { and Skills Development } \\
\text { Levies Act }\end{array}$ & $\begin{array}{l}\text { Establishment of spending levels on the train- } \\
\text { ing and qualification of workers by firms. }\end{array}$ & 1998-1999 \\
\hline
\end{tabular}

Source: Elaborated by the author based on data available in Hirsch (2005).

However, the regulation of the South African labor market took place in parallel with the economic restructuring and with unemployment increasing from I9.3\% to 25.8\% (I996-2000) (Barbosa and Tepassê 2009; Paola and Pons-Vignon 20I3). The hope that a democratic regime with labor protection institutions would reduce unemployment did not meet reality, which led neoclassical interpretations to point out a supposed "rigidity" in the labor market. These institutions, in their turn, demanded greater "flexibility" and ignored the structural roots of unemployment in South Africa, the low economic growth of the period and the dominance of sectors linked to the mineral-energy complex, which are basically capital-intensive (Paola and Pons-Vignon 20I3). In addition, labor institutions were inserted in the context of a "dualistic economy", where thousands of workers were on the margins of the modern and industrial economy, a fact that highlighted the 
need of implementing state assistance for poverty and inequality matters (Hirsch 2005).

Such assistance came in the form of a substantial social security system, which transferred income to individuals with disability, provided support for children, pensions, among others. In I997, when the White Paper for Social Welfare was launched, the South African government has expanded its spending on several social assistance programs, which jumped from R \$Io billion ${ }^{16}$ in 1994 to $\mathrm{R} \$ 38.4$ billion, in 2003 (Hirsch 2005). The income transfer provided by these institutions was particularly important for the black population, which participated with $60 \%$ of the income distributed in the form of retirements, pensions and social programs in 2005 (Barbosa and Tepassê 2009). The total number of social assistance beneficiaries more than doubled between 1996 and 2008 and the share of public spending on health and education as part of total public spending between 2000 and $20 \mathrm{II}$ ranged from I0.9\% to I $2.7 \%$, and from I8.I\% to I $9.2 \%$, respectively (Barbosa and Tepassê 2009; Good Governance Africa 2013).

\section{Conclusion}

Based on the debate about the association between institutions and economic development, the main aim of this study was to present a critical view of the mainstream economic discourse propagated by multilateral organizations and developed countries. This view credits the successful path travelled by advanced economies to a set of "good policies" and "good institutions", which are mostly market friendly and based on the Anglo-Saxon models. The seminal study by South Korean economist Ha-Joon Chang has shown, on a historical perspective, that today's developed countries did not exactly follow the path they now advocate for the periphery of capitalism. On the contrary, they resorted to active policies of state intervention and protection of national industry, whereas their institutional development was slow and often had setbacks (Chang 2004).

The pro-market institutionalist discourse gained strength in the developing countries of capitalism in the late $20^{\text {th }}$ century. Thus, it was possible to see transformations brought about in South Africa since the I990s as the example of a country that was experiencing new institutional change processes. The South African democratic transition took place when the discussion about the role played by institutions gained importance in the

I6 In rands, the South African official currency. 
political and economic debate. Multilateral organizations, such as the World Bank and the IMF, started interpreting the crises and structural issues of developing economies as institutional and governance issues and, in the case of African countries, they started equalizing development policies to poverty-eradication measures.

Nevertheless, the current study has also addressed how the development of a set of institutions - such as democracy, protection of intellectual property rights, financial institutions and an independent central bank, tariffs and trade liberalization, and the labor market-regulating institutions - since the end of the apartheid regime did not necessarily result in better economic and social performance. If, on the one hand, it is quite true that "institutions matter", on the other hand, it is necessary taking into account that the association between institutions and economic development is more complex than what is predicted in the linear "one-size-fits-all" models defended by orthodoxy. British Prime Minister Gordon Brown was right when he told The Economist that it can take generations to develop reliable institutions. The same happened with developed nations, but it is always possible learning from history, as well as thinking about institutional programs capable of reflecting the structural, political, economic, social and cultural conditions of developing countries, without falling into sterile neoliberal models.

\section{References}

Acemoglu, Daron, and James Robinson. 2012. Por que as nações fracassam: as origens do poder, da prosperidade e da pobreza. São Paulo: Elsevier.

Acemoglu, Daron, Simon Johnson, and James Robinson. 200I. "The Colonial Origins of Comparative Development: An Empirical Investigation." American Economic Review, vol. 9I, n. 5: I369-I40I.

Acemoglu, Daron, Simon Johnson, and James Robinson. 2005. "Institutions as a fundamental cause of long-run growth." In Handbook of economic growth, edited by Philippe Aghion and Steven N Durlauf, 386-472. Elsevier.

. 2002. "Reversal of Fortune: Geography and Institutions in the Making of the Modern World Income Distribution." Quarterly Journal of Economics, vol. II7, n. 4: I23I-I294.

Alence, Rod. 2009. "Democracy and development in Africa." The Journal of the International Institute, vol. I6, n. 2. 
Aron, Janine. 200I. "Growth and Institutions: a review of the evidence." The World Bank Research Observer, vol. I5, n. I, feb: 99-I35.

Barbosa, Alexandre de Freitas, and Angela Cristina Tepassê. 2009. "África do Sul pós-apartheid: entre a ortodoxia da política econômica e a afirmação de uma política externa 'soberana'." In Trajetórias Recentes de Desenvolvimento: estudos de experiências internacionais selecionadas Livro 2, organized by José Celso Cardoso, Luciana Acioly and Milko Matijascic, 455-506. Brasília : IPEA.

Bates, Robert H. I98I. Markets and States in Tropical Africa. Berkeley, CA: University of California Press.

. I997. Open Economy Politics. Princeton: Princeton University Press.

Bates, Robert H., John H Coatsworth, and Jeffrey G Willianson. 2007. "Lost Decades: Postindependence Performance in Latin America and Africa." The Journal of Economic History, vol. 67, n. 4, december: 917-943.

Bhorat, Haroon, Alan Hirsch, Ravi Kanbur, and Mthuli Ncube. 2013. "Economic Policy in South Africa past, present and future." In Oxford Companion to the Economics of South Africa, edited by Haroon Bhorat, Alan Hirsch, Ravi Kanbur and Mthuli Ncube. Oxford: Oxford University Press.

Blackden, Mark C. I999. Gender, Growth, and Poverty Reduction. Africa Region Findings \& Good Practice Infobriefs; No. I29, Washington, D.C.: World Bank.

Boettke, Peter, and Alexander Fink. 20II. "Institutions First." Journal of Institutional Economics, vol. 7, n. 4: 499-504.

Bond, Patrick. 2013. BRICS in Africa: anti-imperialist, sub-imperialist or in between? A reader for the Durban summit. Scottsville: University of KwaZulu-Natal.

. 2004. "From racial to class apartheid: South Africa's frustrating decade of freedom." Monthly Review, vol. 55, n. Io.

. 2000. The elite transition: from apartheid to neoliberalism in South Africa. Scottsville: Pluto Press and University of Natal Press.

Buchanan, James M. 2008. "Same Players, Different Game: How Better Rules Make Better Politics." Constitutional Political Economy, vol. I9: I7I-I79. 
Castellano, Fernando López. 20I2. "Economía política del desarrollo, análisis poscolonial y malos samaritanos". Revista Problemas del Desarrollo, 169 (43), junio: 27-50.

Chang, Ha-Joon. 2004. Chutando a Escada: A estratégia de desenvolvimento em perspectiva histórica. São Paulo: Unesp.

. 2007. "Institutional Change and Economic Development: An introduction." In Institutional Change and Economic Development, edited by Ha-Joon Chang. New York: United Nations University Press.

. 20II. "Institutions and economic development: theory, policy and history." Journal of Institutional Economics, vol. 7, n. 4: 473-498.

Christiaensen, Luc, Lionel Demery, and Stefano Paternostro. 2002. Growth, Distribution, and Poverty in Africa: Messages from the 1990s. Policy Research Working Paper; No. 28ı, Washington, D.C.: World Bank. Clague, Christopher, Philip Keefer, Stephen Knack, and Mancur Olson. I996. "Property and Contract Rights in Autocracies and Democracies." Journal of Economic Growth, vol. I, n. 2: 243-276.

Coase, Ronald H. I937. "The Nature of the Firm." Economica, (4): 386-405. . I960. "The Problem of Social Cost." Journal of Law and Economics, (3): I-44.

Coudouel, Aline, Anis A. Dani, and Stefano Paternostro. 2006. Poverty and Social Impact Analysis of Reform: Lessons and Examples from Implementation. World Bank, Washington, D.C.: World Bank.

Dhonte, Pierre, and Ishan Kapur. 1996. "Towards a Market Economy: Structures of Governance." IMF Working Paper, pp. I-I6.

Evans, Peter. 20I0. "Constructing the 2Ist Century Developmental State: potentialities and pitfalls." In Constructing a Democratic Developmental State in South Africa: potentials and challenges, edited by Omano Edigheji. Cape Town: HSRC.

. 2004. "Development as Institucional Change: the Pitfalls of Monocropping and Potentials of Deliberation." Studies in Comparative Institutional Development, v. 38: 30-53.

Fallon, Peter, and Luiz A Pereira de Silva. 1994. South Africa : Stimulating Economic Growth. Africa Region Findings \& Good Practice Infobriefs; No. 2I, Washington, D.C.: World Bank.

Fonseca-Satter, Guilherme. 20II. A África do Sul e o sistema-mundo: da Guerra dos Bôeres à globalização. Lisboa: Centro de Estudos Africanos e Gerpress. 
Gala, Paulo. 2003. "A teoria institucional de Douglass North." Revista de Economia Política, vol. 23, n. 2 (90), junho: 89-108.

Gerschenkron, Alexander. I962. Economic backwardness in historical perspective. Cambridge, Massachusetts: The Belknap Press of Harvard University.

Glaeser, Edward L., Rafael La Porta, Florencio Lopez De-Silanes, and Andrei Shleifer. 2004. "Do Institutions cause growth?" Journal of Economic Growth, vol. 9, n. 3, september: 27I-303.

Good Governance Africa. 2013. Africa Survey: Africa in figures. Good Governance Africa, Johannesburgo: Good Governance Africa.

Hirsch, Alan. 2005. Season of Hope: Economic reform under Mandela and Mbeki. Scottsvile: University of KwaZulu-Natal Press.

Holdt, Karl van. 2013. "South Africa: the transition to violent democracy." Review of African Political Economy, vol. 40, n. I38: 589-604.

IMF. 2000. South Africa: selected issues. IMF Staff Country Report No. 00/42, Washington, D.C.: IMF.

Kaufmann, Daniel, Aart Kraay, and Pablo Zoido-Lobaton. I999. "Governance Matters." Policy Research Working Paper. n. 2196, World Bank, Washington, D.C.

Knack, Stephen, and Philip Keefer. I995. "Institutions and Economic Performance: Cross Country Tests Using Alternative Institutional Measures." Economics Q P Politics, vol. 7, n. 3, november: 207-228.

Landes, David. I998. The Wealth and Poverty of Nations. New York: W.W. Norton and Company.

Looney, Robert E. 20I4. "South Africa's difficult transition." In Handbook of Emerging Economies, edited by Robert E. Looney. London and New York: Routledge.

Marais, Hein. 20II. South Africa pushed to the limit: the political economy of change. London and New York: Zed Books.

Marc, Alexandre, Carol Graham, and Mark Schacter. 1994. Economic Reforms and the Poor: Social Action Programs and Social Funds in Sub-Saharan Africa. Africa Region Findings \& Good Practice Infobriefs; No. I2, Washington, D.C.: World Bank.

Medeiros, Carlos Aguiar. 200I. "Instituições, Estado e mercado no processo de desenvolvimento econômico." Revista de Economia Contemporânea, vol. 5, n. I: 49-76. 
North, Douglass C. I990. Institutions, Institutional change and economic performance. Cambridge: Cambridge University Press.

. I97I. "Institutional Change and Economic Growth. ." Journal of Economic History, vol. 3I, n. I, march: II8-I25.

. I986. "The New Institutional Economics." Journal of Institutional and Theoretical Economics, vol. I42, n. I, march: 230-237.

North, Douglass C., John Joseph Wallis, and Barry R Weingast. 2009. Violence and Social Orders: A Conceptual Framework for Interpreting Recorded Human History. Cambridge: Cambridge University Press.

Paola, Miriam Di, and Nicolas Pons-Vignon. 2013. "Labour market restructuring in South Africa: low wages, high insecurity." Review of African Political Economy, vol. 40, n. 138: 628-638.

Park, Walter G. 2008. "International Patent Protection: I960-2005." Research Policy, vol. 4, n. 37, march: 76I-766.

Pereira, Analúcia Danilevicz. 20ı. "A África do Sul independente: segregação, Apartheid e transição pactuada (I9Io-I994)." In África do Sul: História, Estado e Sociedade, organized by Paulo G. Fagundes Visentini and Analúcia Danilevicz Pereira. Brasília: FUNAG/CESUL.

Polanyi, Karl. 2000. A Grande Transformação: As origens da nossa época. Rio de Janeiro: Campus.

Pons-Vignon, Nicolas, and Aurelia Segatti. 2013. "The art of neoliberalism': accumulation, institutional change and social order since the end of apartheid." Review of African Political Economy, vol. 40, n. I38, dec: 507-518.

Porta, Rafael La, Florencio Lopez De-Silanes, Andrei Shleifer, and Robert Vishny. I999. "The Quality of Government." Journal of Law, Economics and Organization, vol. I5, n. I, april: 222-279.

Portes, Alejandro. 2007. "Instituciones y desarrollo: una revisión conceptual." Desarrollo Económico, vol. 46, n. I84, march: 475-503.

Przeworski, Adam. 2004. "The Last Instance: Are Institutions the Primary Cause of Growth?" European Journal of Sociology, vol. 45, n. 2, august: I65-I88.

Republic of South Africa. I996. "Constitution of the Republic of South Africa." https://www.gov.za/documents/constitution-republic-south-africa-ı996. 
Richter, Rudolf. 2005. "The New Institutional Economics: Its Start, its Meaning, its Prospects." European Business Organization Law Review, vol. 6, n. 2, june: 16I-200.

Riley, Thyra A. I995. South Africa: Reducing Financial Constraints to Emerging Enterprises. Africa Region Findings \& Good Practice Infobriefs; No. 48, Washington, D.C.: World Bank.

Segatti, Aurelia, and Nicolas Pons-Vignon. 2013. "Stuck in stabilization? South Africa's post-apartheid macro-economic policy between ideological conversion and technocratic capture." Review of African Political Economy, vol. 40, n. I38: 537-555.

Seleoane, Mandla. 200I. Socio-economic rights in the South Africa Constitution: Theory and practice. Cape Town: HSRC Press.

Soto, Hernando de. 2000. The Mystery of Capital. London: Bantam Books.

Taylor, Ian. 20i6. "'Meet the new boss: Same as the old boss" South Africa's transition as embourgeoisement." Brazilian Journal of African Studies, vol. I, n. I, jun: II-39.

Tylecote, Andrew. 20I6. "Institutions matter: but which institutions? And how and why do they change?" Journal of Institutional Economics, vol. I2, n. 3, september: 72I-742.

Visentini, Paulo Fagundes. 2010. "Processos de integração na África Austral." In África do Sul: História, Estado e Sociedade, organized by Paulo Fagundes Visentini and Analúcia Danilevicz Pereira, II9-I30. Brasília: FUNAG/CESUL.

Williamson, Oliver E. I979. "Transaction-Cost Economics: The Governance of Contractual Relations." Journal of Law and Economics., vol. 22, n. 2, october: 233-26r.

. I975. Markets and Hierarchies. Analysis and Antitrust Implications. New York: The Free Press.

. I985. The Economic Institutions of Capitalism. New York: The Free Press.

World Bank. 1996. Poverty in sub-saharan Africa: Issues and Recommendations. Africa Region Findings, No. 73, Washington, D.C. : World Bank.

Zanden, Jan Luiten van. 2009. The Long Road to the Industrial Revolution: The European Economy in a Global Perspective, 1000-1800. Boston: Brill. 


\section{ABSTRACT}

The transition to a democratic regime in South Africa in the I990s met the rise of neoliberal policies and the discourse addressing "good institutions" and "good governance" as economic growth drivers. In the case of African countries, the discourse preached by multilateral organizations such as the World Bank and the IMF included the idea that policies focused on eradicating poverty and on encouraging education would also mean development. The aim of the current study is to assess to what extent the adequacy to market-oriented institutional models has contributed to South African development, based on a set of institutions. In order to do so, the current study conducted a literature review about the New Institutional Economics (NIE), which is the main proponent of market-oriented institutions as key to development; it also analyzed the critical view of these linear models. It concludes that the association between institutions and economic development is more complex than that estimated in market-oriented models applied to mainstream institutionalism, mainly for developing countries.

\section{KEYWORDS}

Institutions. Economic Development. South Africa.

Received on December 3, 2020 Accepted on February 12, 2021 